\title{
Penurunan Laktat Dehidrogenase Plasmodium falciparum strain D10 pada pemberian Fraksi Tithonia diversifolia (Hemsley)
}

\author{
Tithonia diversifolia (Hemsley) A.Gray Fractions lower Lactate \\ Dehydrogenase of Plasmodium falciparum strain D10
}

Rul Afiyah Syarif*, Mae Sri Hartati Wahyuningsih, Mustofa, Ngatidjan

Departemen Farmakologi dan Terapi, Fakultas Kedokteran Kesehatan Masyarakat dan Keperawatan, Universitas Gadjah Mada

Corresponding author: Rul Afiyah Syarif: Email: rulafiyah@ugm.ac.id

Submitted: 14-07-2020 Revised: 05-10-2020 Accepted: 05-10-2020

\begin{abstract}
ABSTRAK
Penelitian terdahulu menunjukkan bahwa fraksi ke-6 (F6) merupakan fraksi aktif (F-akt) daun Tithonia diversifolia (Hemsley) A.Gray yang menghambat pertumbuhan Plasmodium. Pertumbuhan parasit ini memerlukan energi yang diperoleh dari aktivitas laktat dehidrogenase (LDH). Penelitian ini bertujuan mengkaji aktivitas antiplasmodium fraksi aktif T. diversifolia terhadap kadar LDH kultur P. falciparum. Kultur Plasmodium falciparum strain D10 stadium cincin dibagi menjadi kelompok eritrosit tidak terinfeksi (KTI), eritrosit terinfeksi (KI), dan eritrosit terinfeksi Plasmodium yang diberi F6 (F-akt) T. diversifolia (KI+F-akt) konsentrasi 9,38-150 $\mu \mathrm{g} / \mathrm{mL}$. Kultur diinkubasi 48 jam. Media kultur diukur kadar LDH-nya secara enzimatik. Adanya perbedaan LDH antar kelompok dianalisa dengan Anova. Penghambatan aktivitas LDH (IC50) ditetapkan dengan analisa probit. Kadar LDH kelompok KI (362,33 \pm 133,18 U/L) lebih tinggi daripada KTI (270,33 \pm $65,85 \mathrm{U} / \mathrm{L})(\mathrm{p}>0,05)$. Pemberian F-akt pada KI menyebabkan kadar LDH parasit lebih rendah daripada KI. Kadar LDH parasit yang diberi F-akt konsentrasi 9,38; 18,75; 37,50; dan $150 \mu \mathrm{g} / \mathrm{mL}$ secara berturut-turut adalah 365,5 \pm 129,5; 210,5 \pm 1,5; 195,5 \pm 81,5; dan 111,5 \pm 53,5 U/L. Tidak ada perbedaan kadar LDH antar kelompok penelitian $(\mathrm{p}>0,05)$. F-akt T. diversifolia mampu menghambat LDH $P$. falciparum strain D10 dengan nilai $\mathrm{IC}_{50}=39,22 \mu \mathrm{g} / \mathrm{mL}$.
\end{abstract}

Kata kunci: Tithonia diversifolia; laktat dehidrogenase; Plasmodium falciparum.

\section{ABSTRACT}

The previous research showed that $6^{\text {th }}$ fraction (F6), an active fraction (F-akt), of Tithonia diversifolia (Hemsley) A.Gray leaves inhibited the Plasmodium growth. The growth of parasites requires energy obtained from the lactate dehydrogenase (LDH) activity. This study aimed to investigate the F6 (an active fraction) of T. diversifolia antiplasmodial activity on LDH levels of $P$. falciparum. The ring stage of $P$. falciparum D10 strain culture was divided into 3 groups, that were Plasmodium-uninfected erythrocytes (KTI), Plasmodium-infected erythrocytes (KI), and Plasmodium- infected erythrocytes treated by F-akt of T. diversifolia (KI+F-akt) $9.38-150 \mu \mathrm{g} / \mathrm{mL}$. The culture was incubated $48 \mathrm{~h}$, the LDH in culture medium then was measured enzymatically. The difference of LDH level among groups was analyzed statistically using Anova. The LDH activity inhibition $\left(\mathrm{IC}_{50}\right)$ was determined by probit analysis. The LDH level of KI group (362.33 $\left.\pm 133.18 \mathrm{U} / \mathrm{L}\right)$ was higher than KTI $(270.33 \pm 65.85 \mathrm{U} / \mathrm{L})(\mathrm{p}>0.05)$. LDH levels of KI+F-akt groups were lower than KI. The LDH level of $P$. falciparum treated by F-akt $9.38 ; 18.75 ; 37.50$; and $150 \mu \mathrm{g} / \mathrm{mL}$ were $365.5 \pm 129.5 ; 210.5 \pm 1.5 ; 195.5 \pm 81,5$; and $111.5 \pm 53.5 \mathrm{U} / \mathrm{L}$, respectively. There were no differences in LDH levels among study groups $(\mathrm{p}>0.05)$. F-akt of $T$. diversifolia inhibits LDH of $P$. falciparum strain D10 with $\mathrm{IC}_{50}$ value $=39.22 \mu \mathrm{g} / \mathrm{mL}$.

Keywords: Tithonia diversifolia; lactate dehydrogenase; Plasmodium falciparum.

\section{PENDAHULUAN}

Resistensi terhadap antimalaria konvensional yang semakin luas berakibat pengendalian dan pengobatan malaria semakin rumit. Untuk mengatasi resistensi ini maka penemuan antimalaria baru sangat diperlukan baik berupa senyawa sintetis maupun dari bahan alam. Antimalaria sintetis kinin dan 
artemisinin merupakan contoh antimalaria yang awalnya bersumber dari tanamam. Penemuan senyawa baru dari tanaman yang secara empirik bermanfaat untuk menanggulangi malaria diharapkan dapat memberikan kontribusi dalam mengatasi resistensi terhadap obat konvensional klorokuin.

Tithonia diversifolia (Hemsley) A. Gray secara empirik digunakan untuk mencegah dan mengobati malaria. Penelitian sebelumnya didapatkan bahwa ekstrak metanol dan fraksi daun $T$. diversifolia mempunyai aktivitas antiplasmodium, dan aktivitas terbaik dimiliki oleh fraksi 6 (F6) (Syarif dkk., 2008; Syarif dkk., 2018). Informasi terkait target kerja fraksi $T$. diversifolia sebagai antiplasmodium sangatlah bermanfaat bila tanaman ini dikembangkan lebih lanjut sebagai obat dari bahan alam.

Target untuk antiplasmodium dapat berlangsung intrasel (di dalam Plasmodium) maupun ekstrasel. Target intrasel terjadi di sitosol, membran, vakuola digesti, mitokondria, dan apikoplas sedangkan ekstrasel dengan cara obat invasi ke eritrosit (Kalra dkk., 2006). Penelitian yang dilakukan oleh Syarif dkk., (2018) mendapatkan bahwa secara in vitro fraksi 5, fraksi 6, dan fraksi $7 T$. diversifolia menghambat polimerisasi heme dalam vakuola digesti. Heme yang tidak dipolimerisasi berakibat matinya parasit tersebut.

Agar bertahan hidup, Plasmodium memerlukan energi yang diperoleh dari metabolisme glukosa melalui proses glikolisis. Laktat dehidrogenase (LDH) merupakan enzim yang terlibat dalam tahap akhir glikolisis (Pradhan dkk., 2009). Dengan demikian keberadaan dan penghambatan aktivitas LDH berpengaruh terhadap kelangsungan hidup Plasmodium dan LDH menjadi target potensial dalam pengembangan obat baru antimalaria (Kalra dkk., 2006).

LDH mengkatalisis secara reversibel perubahan piruvat menjadi laktat. Reduksi piruvat menjadi laktat ini disertai dengan oksidasi $\mathrm{NADH}$ menjadi $\mathrm{NAD}^{+}$, koenzim yang diperlukan untuk memproduksi ATP (Valvona dkk., 2016). Penghambatan LDH memblok regenerasi $\mathrm{NAD}^{+}$dan mencegah pembentukan ATP (Premlata dkk., 2012) sebagai sumber energi Plasmodium. Untuk itu penelitian ini bertujuan mengkaji aktivitas antiplasmodium
F6 T. diversifolia terhadap kadar LDH pada kultur P. falciparum.

\section{METODOLOGI}

Penelitian dilakukan setelah mendapat persetujuan dari Komisi Etik Penelitian Kesehatan FK UGM No KE/FK/18/EC. Penelitian eksperimental laboratorium dilakukan pada $P$. falciparum secara in vitro sebagai subyek penelitian dengan rancangan post-test control group only design.

Daun T. diversifolia diperoleh dari Pakem, Sleman, Yogyakarta dan dideterminasi di Laboratorium Biologi Farmasi, Fakultas Farmasi, Universitas Gadjah Mada. Pembuatan fraksi T. diversifolia dilakukan di Laboratorium Farmakologi dan Terapi, kultur P. falciparum strain D10 dan uji penghambatan LDH dilakukan di Laboratorium Parasitologi, serta pengukuran LDH di Laboratorium Patologi Klinik, Fakultas Kedokteran Universitas Gadjah Mada.

\section{Cara Penelitian}

\section{Fraksinasi T. diversifolia}

T. diversifolia dikeringkan dalam oven bersuhu $50^{\circ} \mathrm{C}$ kemudian diblender untuk mendapatkan serbuk. Pembuatan fraksi dilakukan seperti pada penelitian sebelumnya (Syarif dkk., 2018). Fraksi 6 yang diketahui mempunyai aktivitas antiplasmodium terbaik pada penelitian sebelumnya selanjutnya disebut fraksi aktif (F-akt) (Syarif dkk., 2018), dilakukan uji penghambatan LDH dalam penelitian ini.

\section{Kultur Plasmodium falciparum}

Aktivitas senyawa uji $T$. diversifolia pada $P$. falciparum untuk mengukur pembentukan enzim LDH dilakukan pada mikroplate 96sumuran. Suspensi P. falciparum $(100 \mu \mathrm{L})$ stadium cincin dengan parasitemia $1 \%$ dan hematokrit $1,5 \%$ didistribusikan pada tiap sumuran 96-microplate. Sinkronisasi Plasmodium stadium cincin dilakukan menggunakan sorbitol 5\% (Contreras dkk., 2004). Ada 3 kelompok kultur dalam penelitian ini yaitu kelompok eritrosit tidak terinfeksi Plasmodium (KTI), kelompok terinfeksi Plasmodium (KI), dan kelompok terinfeksi Plasmodium yang diberi $\mathrm{F}$-akt $\mathrm{T}$. diversifolia (KI+F-akt) konsentrasi 9,38; 37,5; 18,75 dan 


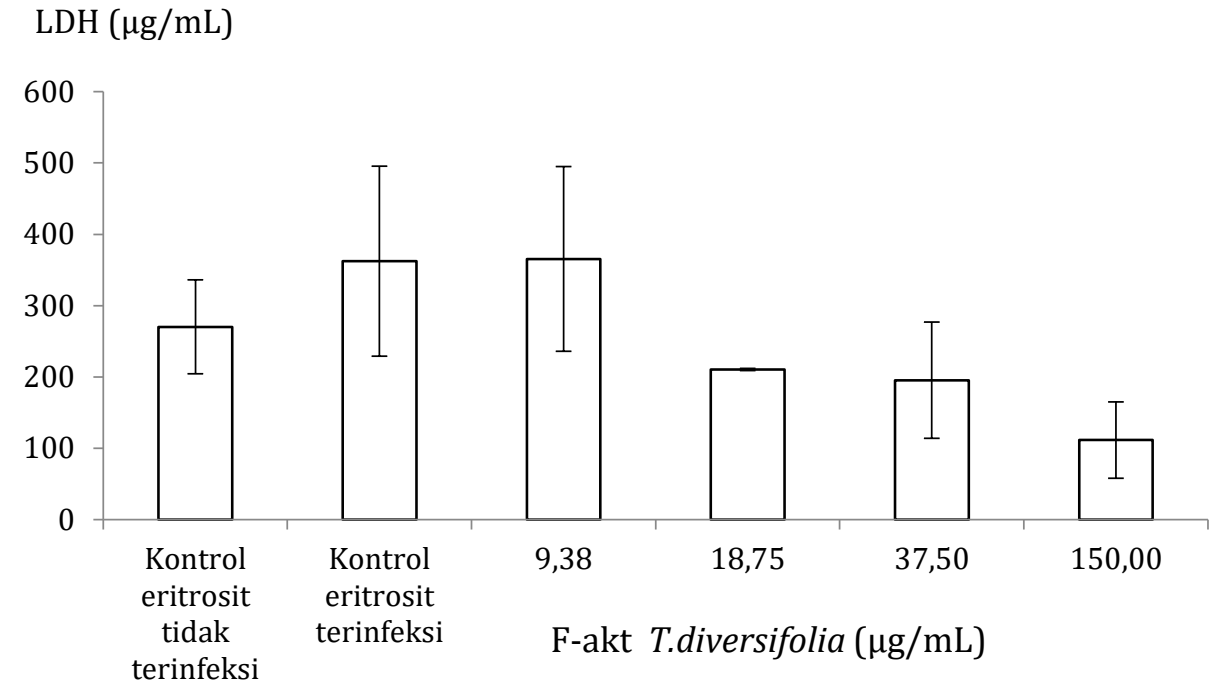

\section{Gambar 1. Kadar LDH \pm SEM $P$. falciparum strain D10 setelah pemberian F-akt T.diversifolia}

$150 \mu \mathrm{g} / \mathrm{mL}$. Tiap uji dilakukan duplikat. Mikroplate kultur diinkubasi selama 48 jam, $\mathrm{CO}_{2}$ $5 \%$, suhu $37^{\circ} \mathrm{C}$. Supernatan dikumpulkan untuk pengukuran LDH.

\section{Pengukuran laktat dehidrogenase}

Masing-masing sampel uji sebanyak 10 $\mu \mathrm{L}$ diukur kadar LDH-nya secara enzimatik menggunakan metode dari Synchron $\mathrm{CX} \circledast$ Systems (Anonim, 2008). Aktivitas laktat dehydrogenase diukur menggunakan reagen laktat dehydrogenase (LD-P) yang mengkatalisis reduksi secara reversibel piruvat menjadi laktat deisertai oksidasi NADH menjadi NAD+. Synchron CX® Systems secara otomatis menyesuaikan volume sampel dengan reagen yang dimasukkan ke dalam kuvet dengan rasio sampel:reagen adalah 1:50. Sistem memonitor perubahan absorbansi pada panjang gelombang $340 \mathrm{~nm}$. Absorbansi yang terukur berbanding lurus dengan aktivitas LD-P dan hal ini digunakan System untuk menghitung dan mengekspresikan aktivitas LDH.

\section{Analisa Hasil}

Data LDH ditampilkan secara deskriptif. Perbedaan rata-rata kadar LDH akibat pemberian F-akt $T$. diversifolia berbagai konsentrasi dianalisa dengan ANOVA program SPSS versi 13.

\section{HASIL DAN PEMBAHASAN \\ Hasil}

Kadar LDH kelompok KI $(362,33 \pm 133,18$

U/L) lebih tinggi daripada KTI $(270,33 \pm 65,85$ U/L) $(p>0,05)$. Pemberian F-akt pada KI menyebabkan kadar LDH parasit lebih rendah, dan semakin tinggi konsentrasi F-akt yang diberikan maka kadar LDH semakin rendah. Kelompok $\mathrm{KI}+\mathrm{F}$-akt konsentrasi terendah menunjukkan kadar LDH yang hampir sama dengan KI. Kadar LDH parasit yang diberi F-akt konsentrasi 9,38; 18,75; 37,50; dan $150 \mu \mathrm{g} / \mathrm{mL}$ secara berturut-turut adalah $365,5 \pm 129,5 ; 210,5$ $\pm 1,5 ; 195,5 \pm 81,5$; dan 111,5 \pm 53,5 U/L (Gambar 1). Tidak ada perbedaan kadar LDH antar kelompok penelitian ( $\mathrm{p}>0,05)$

Semakin tinggi konsentrasi F-akt yang diberikan pada KTI menunjukkan penghambatan pembentukan LDH yang semakin besar (Tabel I). Konsentrasi F-akt yang mampu menghambat sintesis LDH sebesar 50\% (IC 50 ) adalah 39,22 $\mu \mathrm{g} / \mathrm{mL}$.

\section{Pembahasan}

Selama siklus intraeritrosit Plasmodium mendapatkan energi melalui metabolisme glukosa (glikolisis). Laktat dehidrogenase merupakan enzim teminal dalam glikolisis yang mengubah piruvat menjadi laktat dengan kofaktor NADH. LDH mengkatalisis secara 
Tabel I . Kadar LDH dan persentase penghambatan pembentukannya pada $P$. falciparum strain $\mathrm{D}_{10}$ setelah pemberian F-akt T.diversifolia

\begin{tabular}{ccccc}
\hline $\begin{array}{c}\text { F-akt T.diversifolia } \\
(\boldsymbol{\mu g} / \mathbf{m L})\end{array}$ & $\begin{array}{c}\text { Rata-rata LDH } \pm \\
\text { SEM (U/L) }\end{array}$ & Nilai p LDH & $\begin{array}{c}\text { \% } \\
\text { penghambatan } \\
\text { LDH } \pm \text { SEM }\end{array}$ & $\begin{array}{c}\text { Nilai IC } \mathbf{5 0}_{\mathbf{5 0}} \\
(\boldsymbol{\mu g} / \mathbf{m L})\end{array}$ \\
\hline 9,38 & $365,5 \pm 265,84$ & & - & \\
18,75 & $210,5 \pm 97,59$ & $\mathrm{p}>0,05$ & $41,92 \pm 79,37$ & \\
37,50 & $195,5 \pm 128,44$ & & $46,07 \pm 66,96$ & 39,22 \\
150 & $111,5 \pm 55,81$ & & $69,25 \pm 26,67$ & \\
KI & $362,33 \pm 133,18$ & & & \\
KTI & $270,33 \pm 65,85$ & & & \\
\hline
\end{tabular}

reversibel perubahan piruvat menjadi laktat. Reduksi piruvat menjadi laktat dalam tubuh manusia disertai dengan oksidasi NADH menjadi $\mathrm{NAD}^{+}$yang selanjutnya digunakan untuk memproduksi ATP (Garba \& Ubom, 2005; Valvona dkk., 2017). 3-acetyl pyridine adenine dinucleotide $\left(\mathrm{APAD}^{+}\right)$dalam Plasmodium merupakan analog koenzim $\mathrm{NAD}^{+}$manusia. Seperti halnya dalam tubuh manusia, LDH Plasmodium $(p \mathrm{LDH})$ mengkatalisis secara reversibel perubahan piruvat menjadi laktat dan mengubah APADH menjadi $\mathrm{APAD}^{+}$(Kalra dkk., 2006).

Sebelum diberi perlakuan, kultur $P$. falciparum disinkronisasi menjadi stadium cincin. Setelah 48 jam inkubasi dengan F-akt, medium kultur dikumpulkan untuk pemeriksaan LDH. Inkubasi 48 jam dipilih karena aktivitas maksimal LDH terjadi ketika kultur Plasmodium diinkubasi 36 - 48 jam, yaitu saat stadium trofozoit dan skizon lebih dominan karena stadium cincin telah berkembang menjadi stadium tersebut. Selain dipengaruhi oleh lama inkubasi, aktivitas pLDH juga berhubungan dengan jumlah parasit dalam plasma darah (parasitemia) dan kadar hematokrit. Aktivitas LDH dapat dideteksi bila parasitemia 1-2\% dan hematokrit 1,5\% (Basco $d k k ., 1995$; Verma dkk., 2013).

Penelitian yang dilakukan oleh Vivas dkk. (2005) mendapatkan bahwa aktivitas pLDH dan ekspresi RNA pLDH P. falciparum stadium trofozoit lebih besar daripada stadium cincin, dan pada stadium trofozoit lebih peka terhadap antimalaria OXD1. Hal ini dimungkinkan berkaitan dengan kenaikan kebutuhan energi stadium trofozoit yang konsisten dengan kenaikan glikolisis sebagai jalur metabolisme esensial untuk kelangsungan hidup Plasmodium stadium ini.
LDH merupakan enzim esensial di semua organ tubuh, yang terletak dalam sitosol (intrasel). Adanya LDH dalam medium atau ekstrasel menunjukan bahwa telah terjadi kerusakan atau kematian sel, dalam hal ini eritrosit dan atau Plasmodium (Cobben dkk., 1997). LDH yang terukur dalam sampel dengan menggunakan metode dari Synchron CX® Systems dimungkinkan adalah $p$ LDH dan human LDH ( $h$ LDH) karena metode ini tidak spesifik mengukur hanya $p \mathrm{LDH}$.

Kadar LDH pada KI lebih tinggi dibandingkan dengan KTI maupun $\mathrm{KI}+\mathrm{F}$-akt. Hal ini dapat terjadi karena ambilan glukosa pada eritrosit terinfeksi Plasmodium 30-50 kali lebih besar daripada yang tidak terinfeksi, dan hampir semua glukosa ini diubah menjadai laktat (Jensen dkk., 1983 cit., Vivas dkk., 2005). Aktivitas metabolisme yang tinggi ini tercermin dalam bentuk tingginya kadar LDH pada eritrosit terinfeksi (Roth, 1990 cit., Vivas dkk., 2005).

Kelompok KI+F-akt konsentrasi terendah menunjukkan kadar LDH yang hampir sama dengan KI. Hal ini menunjukkan bahwa konsentrasi terendah F-akt tidak mampu membunuh Plasmodium. Lain halnya dengan konsentrasi F-akt yang lebih tinggi. Kelompok $\mathrm{KI}+\mathrm{F}$-akt menunjukkan kadar $\mathrm{LDH}$ yang semakin bertambah rendah dengan semakin tingginya konsentrasi F-akt. Hal ini menunjukkan bahwa semakin tinggi konsentrasi F-akt maka semakin tinggi Plasmodium yang mati di waktu awal inkubasi sehingga tidak menginfeksi eritrosit lainnya. Akibatnya di akhir inkubasi lebih banyak eritrosit yang utuh dan tidak lisis. Selain tidak menginfeksi eritrosit lain, kadar LDH yang lebih rendah pada KI+F-akt daripada KTI kemungkinan karena F-akt mempunyai efek 
proteksi sehingga eritrosit dapat bertahan lama (tidak lisis). Namun untuk membuktikan hal ini perlu sediaan apus darah yang sayangnya tidak dilakukan dalam penelitian ini.

Penelitian ini mendapatkan bahwa $\mathrm{IC}_{50} \mathrm{~F}$ akt dalam menghambat kadar LDH $P$. falciparum strain D10 (sensitif klorokuin) sebesar 39,22 $\mu \mathrm{g} / \mathrm{mL}$. Nilai ini lebih tinggi daripada $\mathrm{IC}_{50} \mathrm{~F}$-akt $(13,63 \pm 1,43 \mu \mathrm{g} / \mathrm{mL})$ dalam menghambat pertumbuhan $P$. falciparum strain FCR3 (strain resisten klorokuin) yang diperoleh dengan cara menghitung parasitemia sediaan apusan darah menggunakan mikroskop cahaya. Meskipun pengukuran LDH juga dapat dipakai untuk mengetahui aktivitas antiplasmodium suatu senyawa, namun $\mathrm{IC}_{50}$ yang diperoleh tidak sama. Hal ini dapat disebabkan strain Plasmodium yang berbeda atau F-akt $T$. diversifolia lebih spesifik bekerja/berefek pada $P$. falciparum resisten klorokuin. Jumlah pengulangan percobaan yang terbatas (hanya 2) dalam penelitian ini sehingga menyebabkan SEM yang besar juga merupakan salah satu penyebab IC $_{50}$ LDH lebih besar daripada $\mathrm{IC}_{50}$ aktivitas antiplasmodium secara mikroskopik. Untuk membuktikan hal tersebut sebaiknya dilakukan penelitian mengukur aktivitas penghambatan produksi LDH di P. falciparum strain FCR3 dan menambah jumlah pengulangan uji penghambatan LDH.

\section{KESIMPULAN}

F-akt menghambat aktivitas laktat dehidrogenase P. falciparum strain D10 (strain sensitif klorokuin) dengan IC $_{50}$ sebesar 39,22 $\mu \mathrm{g} / \mathrm{mL}$. Penelitian serupa sebaiknya dilakukan pada P. falciparum resisten klorokuin.

\section{UCAPAN TERIMAKASIH}

Terimakasih diucapkan kepada Kementerian Kesehatan Republik Indonesia yang telah memberikan dana penelitian melalui Riset Pembinaan Ilmu Pengetahuan dan Teknologi Kedokteran (Risbin Iptekdok).

\section{DAFTAR PUSTAKA}

Ambre, P.K., Pissurlenkar, R.R.S., Jagyasi, A.S., ule, R.A., Khedkar, V., Barhatel, C.R., Vivas, L., Tripathi, A.K., Sullivan, D., Birkinshaw, R., Brady, L., Iyer, K., and Coutinho, E.C. 2012. Molecular Modeling Studies, Synthesis and Biological Evaluation of Novel Plasmodium falciparum Lactate
Dehydrogenase ( $p f L D H)$ Inhibitors. AntiInfective Agents 10: 55-71. https://www.researchgate.net/publicati on/259674306

Anonim. 2008. SYNCHRON CX® System(s) Chemistry Information Sheet: LD-P Lactate Dehydrogenase. Beckman Coulter, Inc.

Basco, L.K., Marquet, F, Makler, M.M, Le Bras, J. 1995. Plasmodium falciparum and Plasmodium vivax: lactate dehydrogenase activity and its application for in vitro drug susceptibility assay. Exp Parasitol 80(2):260-71. https://pubmed.ncbi.nlm.nih.gov/78958 36/

Cobben N. A. M., Drent, M., Schols, A. M. W. J., Lamers R. J. S., Wouters E. F. M., and Van Dieijen-Visser, M. P.1997. Serum lactate dehydrogenase and its isoenzyme pattern in ex-coalminers. Respiratory Medicine 91: 616-623. https://www.mendeley.com/catalogue/ d7eb36da-5dff-37be-bf661bfe2eb8ab19/

Contreras, C.E., Rivas, M.A., Dominguez, J., Charris, J., Palacios, M., Bianco, N.E., and Blanca, I. 2004. Stage-specifics Activity of Potential Antimalarial Compounds Measured in vitro by Flow Cytometry in Comparison to Optical Microscopy and Hypoxanthine Uptake. Mem Inst Cruz. 99(2):179-84.

https://pubmed.ncbi.nlm.nih.gov/15250 $472 /$

Garba, I.H. dan Ubom, G.A.2005. Total serum lactate dehydrogenase activity in acute Plasmodium falciparum malaria infection. Singapore Med J 46(11):632-634

Grace, N.N., Rainer, B.W., Barbara, G, Erie, N.L., and Victoris, N. 2004. Utilization of Weed Species as Sources of Traditional Medicines in Central Kenya. Lyonia., 7(2) : 71-87.

Kalra B.S., Chawla S., Gupta P., and Valecha N. 2006. Screening of antimalarial drugs: An overview. Indian J Pharmacol 38 (1): 5-12

Pradhan, A, Tripathi, A.K., Desai, P.V., Mukherjee, P.K., Avery, M.A., Walker, L.A., Tekwani, B.L. 2009. Structure and function of Plasmodium falciparum malate dehydrogenase: Role of critical amino acids in co-substrate binding 
pocket. Biochimie 91: 1509-1517. http://dx.doi.org/10.1016/j.biochi.2009. 09.005

Syarif RA, Wahyuningsih MSH, Mustofa, Ngatidjan, Kurniawan $\mathrm{H}, \mathrm{Al}$ Hilal SR. 2008. Aktivitas antiplasmodium in vitro ekstrak kembang bulan (Tithonia diversifolia (Hemsley) A.Gray) terhadap Plasmodium falciparum. Majalah Obat Tradisional 13 (43): 3- 9.

Syarif, R.A., Wahyuningsih, M.S.H, Mustofa, Ngatidjan. 2018. Antiplasmodial activity and onset speed of growth inhibition of Tithonia diversifolia (Hemsley) A.Gray leave fractions on Plasmodium falciparum. Trop. J. Pharm 17 (11): 22132218.

https://www.tjpr.org/admin/12389900 798187/2018_17_11_15.pdf

Valvona, C.J., Fillmore, H.L., Nunn, P.B., Pilkington, G.J. 2016. REVIEW The
Regulation and Function of Lactate Dehydrogenase A: Therapeutic Potential in Brain Tumor. Brain Pathology 26: 3-17

Verma, P., Biswas, S., Mohan, T., Ali, S., \& Rao, D.N. 2013. Detection of histidine rich protein \& lactate dehydrogenase of Plasmodium falciparum in malaria patients by sandwich ELISA using inhouse reagents. Indian J Med Res 138: 977-987.

https://pubmed.ncbi.nlm.nih.gov/24521 645/

Vivas, L., Easton, A., Kendrick, H., Cameron, A., Lavandera, J.L., Barros, D., de las Heras, F.G., Brady, R.L., and Croft, S,L. 2005. Plasmodium falciparum: stage specific effects of a selective inhibitor of lactate dehydrogenase. Exp Parasitol 111(2):105-14.

https://pubmed.ncbi.nlm.nih.gov/16098 967/ 